\title{
Extant freshwater ostracodes (Crustacea: Ostracoda) from Lago Petén Itzá, Guatemala
}

\section{Liseth Pérez ${ }^{1}$, Julia Lorenschat ${ }^{1}$, Mark Brenner $^{2}$, Burkhard Scharf $^{1} \&$ Antje Schwalb ${ }^{1}$}

1. Institute of Environmental Geology, University of Braunschweig, Langer Kamp 19c, 38106, Braunschweig, Germany; 1.perez@tu-bs.de,j.lorenschat@tu-bs.de, burkhard.w.scharf@t-online.de, antje.schwalb@tu-bs.de

2. Department of Geological Sciences \& Land Use and Environmental Change Institute, University of Florida, Gainesville, Florida, FL 32611, USA; brenner@ufl.edu

$$
\text { Received 09-VII-2009. C Corrected 04-II-2010. Accepted 02-III-2010. }
$$

\begin{abstract}
Ostracode taxonomy has been of great interest because of their possible use as indicator species in climate and ecosystem changes. In Central and South America, few studies have been carried out and this study includes a contribution to the group. Eleven ostracode species were collected in Lago Petén Itzá $\left(\sim 100 \mathrm{~km}^{2}\right)$, the second largest lowland lake in Guatemala, and from its inflow tributary, Río Ixlú in November 2005 and February 2008. Twenty-seven surface sediment samples were retrieved at water depths from the littoral zone to the lake's maximum depth $(>160 \mathrm{~m})$. Hard and soft parts of ostracodes were analyzed, and each ostracode species was described for taxonomy, size, ecology, biology and geographic distribution. Species recorded include: Candonocypris serratomarginata?, Cypretta brevisaepta?, Cypridopsis okeechobei, Cytheridella ilosvayi, Darwinula stevensoni, Heterocypris punctata, Limnocythere opesta, Physocypria globula, Pseudocandona sp., Stenocypris major and Strandesia intrepida. Most of the species have a neotropical distribution, two are distributed world-wide (D. stevensoni and S. major), and C. okeechobei and P. globula display nearctic and neotropical distributions. We present new records of C. brevisaepta?, C. serratomarginata?, S. major, and S. intrepida in Guatemala. Physocypria globula was misidentified previously in Lago Petén Itzá as Cypria petenensis, Pseudocandona sp. was misidentified as Candona sp., and C. okeechobei was identified in the past as C. vidua. Limnocythere opesta is the only endemic species of the Petén Lake District, Guatemala. The most abundant and widely distributed species in the lake are P. globula, C. okeechobei, and Pseudocandona sp. Species restricted to the littoral zones and water depths $<15 \mathrm{~m}$ are C. brevisaepta?, D. stevensoni, H. punctata, and S. intrepida. Limnocythere opesta, C. ilosvayi, C. okeechobei, and Pseudocandona sp. are distributed from the littoral zone to a depth of $40 \mathrm{~m}$. Species collected only in the Ixlú tributary and in a littoral zone on the west side of the lake were $C$. serratomarginata? and S. major. During November, live adult L. opesta and C. okeechobei were abundant, but no C. brevisaepta? or C. serratomarginata? adults were found. Adult specimens of C. ilosvayi were more abundant in February. In general, ostracodes collected were smaller than those reported in the literature. An accurate taxonomy will improve the use of ostracode fossil assemblages in long sediment cores when reconstructing past climatic and environmental changes in the northern lowland Neotropics. Rev. Biol. Trop. 58 (3): 871-895. Epub 2010 September 01.
\end{abstract}

Key words: freshwater ostracodes, Lago Petén Itzá, Guatemala, Neotropics, taxonomy, Physocypria globula.

Ostracodes are microscopic, bivalved crustaceans, usually $0.4-3 \mathrm{~mm}$ long, with valves of low-Mg calcite. The two valves comprise the carapace and protect the soft body parts. The valves are closed by adductor muscles that are attached to the carapace. These muscles leave scars on the valves and can be used to identify individuals to the family and superfamily levels. Other important taxonomic characters used for identification are the structure of the marginal zone of the valve, the external valve surface, pigmentation of the carapace, and differences in appendages and other soft parts (Dole-Olivier et al. 2000, Meisch 2000, Horne 
et al. 2002). Ostracodes live in fresh, brackish, and marine waters, including streams, springs, ponds, lakes, estuaries and oceans. Some taxa are found in groundwaters, semi-terrestrial environments, or even in terrestrial plants that accumulate water, such as bromeliads. Non-marine ostracode species display diverse lifestyles. Some are benthic, living on or within the bottom substrate, while others are nektobenthic, with swimming abilities, but also live on the bottom substrate or plants. Some species can live in interstitial environments (Mezquita et al. 2005). Ostracodes display different tolerances to water column physico-chemical variables. Eurytopic species are adapted to a wide range of environmental conditions, while stenotopic species are adapted to a narrow range of environmental conditions. Like other crustaceans, ostracodes moult, generally passing through eight stages to reach adulthood. An ostracode's life cycle may last a few months or $>2$ years (Horne et al. 2002, Smith $\&$ Horne 2002). Ostracodes constitute a model group in ecological and evolutionary studies, and are used as indicator species in climate and ecosystem change studies (Butlin \& Menozzi 2000, Griffiths \& Holmes 2000, Holmes \& Chivas 2002, Horne et al. 2002, Smith \& Horne 2002, Schwalb 2003, Viehberg 2004, Martens et al. 2008).

There has been great interest in the taxonomy of ostracodes from Central America and South America (Klie 1939, Ferguson et al. 1964, Swain \& Gilby 1964, Goulden 1966, Würdig 1983, Roessler 1990a, b, Cusminsky et al. 2005), as well as their zoogeography and distribution (Kotzian 1974, Broodbakker 1984, Collado et al. 1984, Martens 1984, Martens \& Behen 1994), shell geochemistry (Cross et al. 2000), valve isotopic composition (Hodell et al. 1995, Leyden et al. 1996, Whitmore et al. 1996, Curtis et al. 1996, 1998, 1999, Brenner et al. 2002, Rosenmeier et al. 2002a, b, Markgraf et al. 2003, Schwalb 2003, Hillesheim et al. 2005, Hodell et al. 2005), ecology (Deevey et al. 1980, Pérez et al. 2008, 2009, 2010), and use as hydrochemical bio-indicators (Laprida 2006). Few studies, however, have been carried out on the Yucatán Peninsula, i.e. in the lowlands of Guatemala, México and Belize.

Most ostracode studies in the Neotropics have dealt with their taxonomy or use as paleoenvironmental indicators. Taxonomic studies of ostracodes from Lago Petén Itzá began in 1925 with collections by Dampf and identifications by Brehm (1939). Brehm (1932) reported the following ostracode species in an early publication on the freshwater fauna of Guatemala and México: Cypria pelagica, Dolerocypris opesta, and Limnocythere sp. In a second publication, Brehm (1939) presented new results on the microfauna of Lago Petén Itzá. Studied groups included Cladocera, Rotifera and Ostracoda. Brehm reported a new ostracode species, Limnocythere opesta n. sp. Brehm's identification of C. pelagica ultimately led to a controversy. Ferguson et al. (1964) identified ostracodes collected in the lake earlier by E.S. Deevey. They suggested the species name Cypria pelagica used by Brehm (1932) was invalid, and named the species Cypria petenensis. The epithet pelagica was first used by Klie (1933) to describe the subspecies Cypria javana pelagica and thus the subsequent use of this name is invalid. The species found in Guatemala was thought to be endemic to lakes in the Petén region of northern Guatemala, hence the species epithet petenensis. Confusion over the taxonomic status of this nekto-benthic ostracode species ended when Curtis et al. 1998 collected them in lake sediments of Lago Petén Itzá, and used their valves for isotopic analysis. They placed the taxon in the correct genus, Physocypria. Differences between the two genera are described later. We propose that the correct name for the species in Lago Petén Itzá is Physocypria globula (Furtos, 1936).

This paper indicates that there have been some disagreements regarding identification of ostracodes from Lago Petén Itzá. Nevertheless, isotope measurements on their valves have been used as tools for paleoenvironmental reconstruction (Curtis et al. 1998, Rosenmeier et al. 2002a, Hillesheim et al. 2005). Accurate taxonomy is crucial for paleoecological interpretation 
of changes in fossil species assemblages in lake sediments. With this in mind, we present a taxonomic overview of the ostracodes in Lago Petén Itzá, with information on their size, biology, ecology, and zoogeography.

\section{MATERIALS AND METHODS}

Study site and collection of ostracodes: Lago Petén Itzá $\left(17^{\circ} 0^{\prime} \mathrm{N}, 89^{\circ} 51^{\prime} \mathrm{W}\right)$ is the second largest lake in the Guatemala lowlands (Fig. 1A), with an area of $\sim 100 \mathrm{~km}^{2}$ and a maximum depth of $>160 \mathrm{~m}$. Its sediment record appears to span $>200000$ years (Müller 2009 , pers. comm.), making it one of the few extant ancient lakes of the world. It is located in Petén, northern Guatemala. The lake originated from tectonism and limestone dissolution. The lake surface lies at about $110 \mathrm{~m}$.a.s.l. The northern basin is deep and has steep slopes. The southern basin is shallower and the areal extent of its seasonally swampy shores is related to lake level variation. The thermocline of the lake is located between 20 and $40 \mathrm{~m}$ water depth, and the water body is thermally stratified throughout most of the year (Brezonik \& Fox 1974, Hillesheim et al. 2005). Ambient air temperature ranges from $22.3^{\circ} \mathrm{C}$ (January) to $29.8^{\circ} \mathrm{C}$ (May). The hydrologic budget of the lake is controlled mainly by evaporation and precipitation. There is a small input stream, the Río Ixlú, but Lago Petén Itzá lacks an overland outflow and is an effectively closed basin (Anselmetti et al. 2006, MARN-AMPI 2008, Müller et al. 2009).

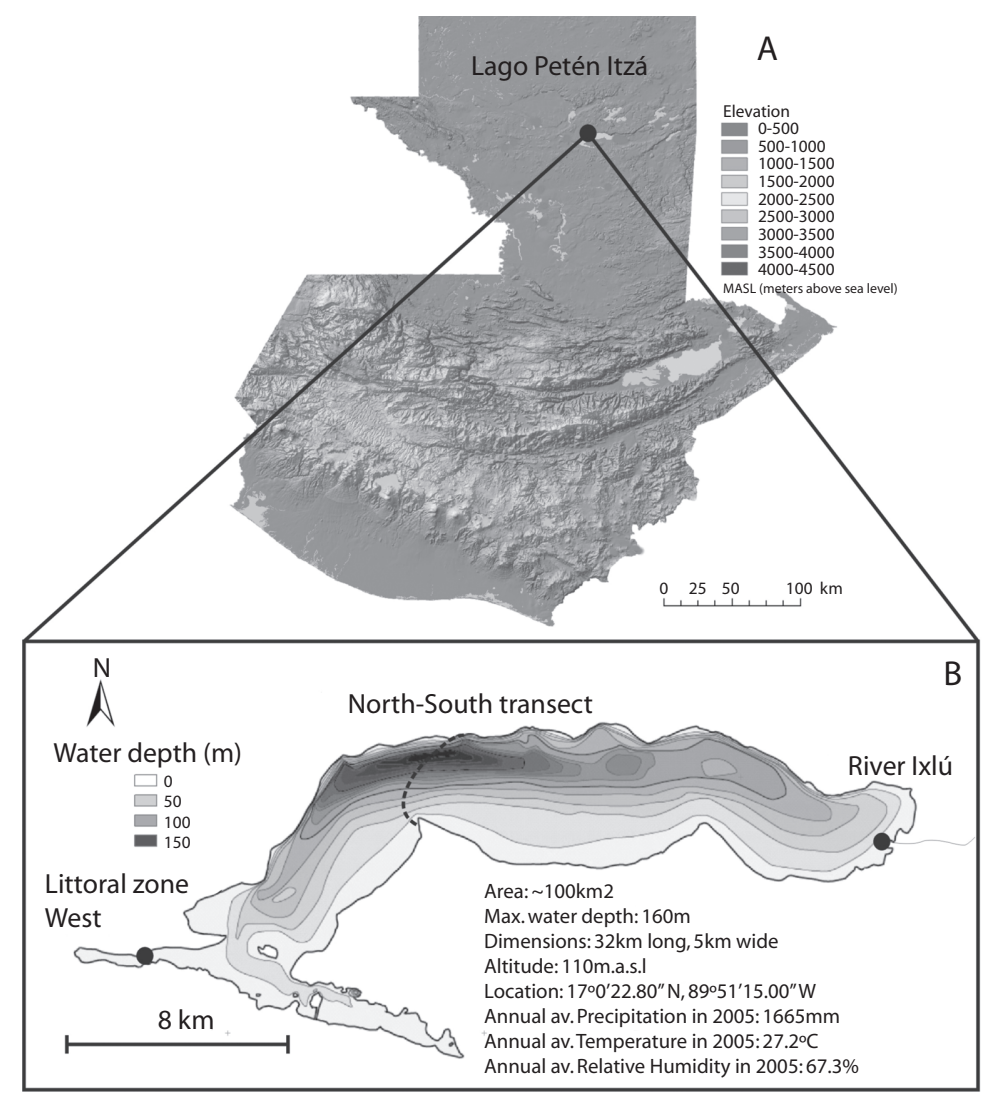

Fig. 1. (A) Lago Petén Itzá, Guatemala; (B) Sites where surface sediment samples were collected for taxonomic analysis: North-South water depth transect, western littoral zone and river Ixlú. 
Twenty-seven surface sediment samples were collected in November 2005 from the littoral zone of Lago Petén Itzá, across a N-S transect and at water depths to a maximum of $160 \mathrm{~m}$. Two additional samples were collected in February 2008 from the littoral zone in the west and from the Río Ixlú tributary in the east (Fig. 1B). Surface sediment samples were retrieved using an Ekman grab. Adult ostracodes were collected among aquatic plants in the littoral zone using a net with a mesh size of $250 \mu \mathrm{m}$. We added $96 \%$ ethanol to the surface sediments to preserve soft body parts. Details of the lake water physico-chemical properties are in Pérez et al. (2010).

Ostracode identification: Ostracodes were selected from surface sediment samples with fine brushes. Soft parts were detached from both valves using entomological needles, dissected, and mounted with Hydro-Matrix ${ }^{\circledR}$ onto cover slides. Photographs for analysis of soft and hard parts were taken using a Leica DM5000B microscope and a Leica DFC 320 digital camera. Scanning Electron Microscope (SEM) pictures of ostracode valves and carapaces were made in the Biocenter Grindel and Zoological Museum of the University of Hamburg, Germany. SEM pictures were taken with a field emission scanning electron microscope LEO 1525. Length and height of valves from each species were measured in $\mu \mathrm{m}$ (Table 1). The $\mathrm{n}$ in the table indicates the number of valves measured. Ostracode valves and soft parts from the British Museum, London and private collections were compared with our samples. For identification and additional ecological information we used primarily the works of Brehm (1939), Furtos (1933, 1936a, b), and Deevey et al. (1980). Ostracode specimens are stored at the Institute of Environmental Geology, University of Braunschweig, Germany.

\section{RESULTS}

Taxonomy of ostracodes: Eleven ostracode species were identified in surface sediment samples from Lago Petén Itzá and in a small stream tributary in the east. The species assemblage is composed of two limnocytherids ( $\mathrm{Lim}$ nocythere opesta (Brehm, 1939), Cytheridella ilosvayi (Daday, 1905), two candonids (Physocypria globula, Pseudocandona sp.), one darwinulid (Darwinula stevensoni (Brady \& Robertson, 1870)) and six cypridids (Cypretta brevisaepta (Furtos, 1934)?, Cypridopsis okeechobei (Furtos, 1936), Candonocypris serratomarginata (Furtos, 1936)?, Heterocypris punctata (Keyser, 1976), Stenocypris major (Brady, 1886) and Strandesia intrepida (Furtos, 1936). Classification of the species is as follows:

CLASS OSTRACODA Latreille, 1806

ORDER PODOCOPIDA Sars, 1866

Suborder Podocopina Sars, 1866

Infraorder Cypridocopina Jones, 1901

Superfamily Cypridoidea Baird, 1845

Family Candonidae Kaufmann, 1900

Subfamily Candoninane Kaufmann, 1900

Genus: Pseudocandona Kaufmann, 1900

Pseudocandona sp.

Subfamily Cyclocypridinae Kaufmann, 1900

Genus: Physocypria Vavra 1897

Physocypria globula Furtos, 1933

Family Cyprididae Baird, 1845

Subfamily Cyprettinae Hartmann, 1964

Genus: Cypretta (Vavra, 1895)

Cypretta brevisaepta? Furtos, 1934 
TABLE 1

Biometric characteristics of adult ostracodes from Lago Petén Itzá

\begin{tabular}{|c|c|c|c|c|c|}
\hline Species & Sex & Valve & Length $(\mu \mathrm{m})$ & Height $(\mu \mathrm{m})$ & $\mathrm{n}$ \\
\hline \multirow[t]{2}{*}{ Candonocypris serratomarginata? } & $?$ & RV & --- & --- & --- \\
\hline & & LV & $1700-1762$ & $900-912$ & 2 \\
\hline \multirow[t]{2}{*}{ Cypretta brevisaepta? } & $?$ & RV & $538-667$ & $404-520$ & 3 \\
\hline & & LV & 588 & 452 & 1 \\
\hline \multirow[t]{4}{*}{ Cypridopsis okeechobei } & Female & RV & $495-540$ & $284-303$ & 19 \\
\hline & & LV & $507-535$ & $288-300$ & 10 \\
\hline & Male & RV & $495-528$ & $275-289$ & 20 \\
\hline & & LV & $493-506$ & $284-300$ & 17 \\
\hline \multirow[t]{4}{*}{ Cytheridella ilosvayi } & Female & RV & $785-980$ & $394-513$ & 29 \\
\hline & & LV & $770-957$ & $396-515$ & 26 \\
\hline & Male & RV & $660-787$ & $347-406$ & 25 \\
\hline & & LV & $634-745$ & $343-396$ & 23 \\
\hline \multirow[t]{2}{*}{ Darwinula stevensoni } & Female & RV & $611-707$ & $228-278$ & 28 \\
\hline & & LV & $587-672$ & $221-273$ & 29 \\
\hline \multirow[t]{4}{*}{ Heterocypris punctata } & Female & RV & --- & --- & --- \\
\hline & & LV & $1007-1063$ & $573-624$ & 4 \\
\hline & Male & RV & $999-1050$ & $552-586$ & 5 \\
\hline & & LV & $1020-1068$ & $579-612$ & 3 \\
\hline \multirow[t]{4}{*}{ Limnocythere opesta } & Female & RV & $446-492$ & $230-254$ & 25 \\
\hline & & LV & $449-512$ & $230-260$ & 25 \\
\hline & Male & RV & $486-545$ & $228-263$ & 27 \\
\hline & & LV & $492-550$ & $229-266$ & 29 \\
\hline \multirow[t]{4}{*}{ Physocypria globula } & Female & RV & $505-649$ & $324-449$ & 29 \\
\hline & & LV & $504-667$ & $320-446$ & 28 \\
\hline & Male & RV & $514-556$ & $320-329$ & 7 \\
\hline & & LV & $498-565$ & $364-307$ & 21 \\
\hline \multirow[t]{4}{*}{ Pseudocandona $\mathrm{sp}}$. & Female & RV & $621-720$ & $269-310$ & 17 \\
\hline & & LV & $603-722$ & $273-321$ & 15 \\
\hline & Male & RV & $692-807$ & $312-369$ & 19 \\
\hline & & LV & $696-837$ & $320-393$ & 25 \\
\hline \multirow[t]{2}{*}{ Stenocypris major } & Female? & RV & $1193-1482$ & $516-618$ & 2 \\
\hline & & LV & --- & --- & --- \\
\hline \multirow[t]{4}{*}{ Strandesia intrepida } & Female? & RV & $1082-1158$ & $628-664$ & 4 \\
\hline & & LV & $1026-1145$ & $555-613$ & 2 \\
\hline & Male & RV & 1042 & 590 & 1 \\
\hline & & LV & 1054 & 587 & \\
\hline
\end{tabular}

RV: Right valve; LV: Left valve. Species are presented in alphabetical order. 
Subfamily Cypricercinae McKenzie, 1971

Genus: Strandesia Stuhlmann, 1888

Strandesia intrepida Furtos, 1936

Subfamily Cypridopsinae Kaufmann, 1900

Genus: Cypridopsis Brady, 1868

Cypridopsis okeechobei Furtos, 1936

Subfamily Cyprinotinae Bronshtein, 1947

Genus: Heterocypris Claus, 1893

Heterocypris punctata Keyser, 1975

Subfamily Herpetocypridinae Kaufmann, 1900

Genus: Candonocypris Vávra, 1891

Candonocypris serratomarginata? (Furtos, 1936)

Genus: Stenocypris Sars, 1889

Stenocypris major (Baird, 1859)

Infraorder Cytherocopina Gründel, 1967

Superfamily Cytheroidea Baird, 1850

Family Limnocytheridae Klie, 1938

Subfamily Limnocytherinae Klie, 1938

Genus: Limnocythere Brady, 1868

Limnocythere opesta Brehm, 1939

Subfamily Timiriaseviinae Mandelstam, 1960

Genus: Cytheridella Daday, 1905

Cytheridella ilosvayi Daday, 1905

Infraorder Darwinulocopina Sohn, 1988

Superfamily Darwinuloidea Brady \& Norman, 1889

Family Darwinulidae Brady \& Norman, 1889

Genus Darwinula Brady \& Robertson, 1885

Darwinula stevensoni (Brady \& Robertson, 1870)

Differences between species identified in this study and those in other published literature are presented in Table 2. Species reported for the first time in Lago Petén Itzá are: $C$. brevisaepta?, D. stevensoni, C. serratomarginata?, S. major, and S. intrepida. Cypridopsis okeechobei was previously identified as $C$. vidua and C. rhomboidea. Pseudocandona sp. was misidentified in the past as Candona sp. Cytheridella ilosvayi and L. opesta were correctly identified in previous investigations.

The following section presents, in alphabetical order, species identified in this study, with a description of valves and soft parts for species that were not identified down to species level, or species for which only valves were found and for which identification thus remains uncertain (e.g. Candonocypris serratomarginata?, Cypretta brevisaepta?, and Pseudocandona sp.). Accompanying each taxon is an abbreviated synonymy list, as well as references for extended lists, an explanation of the type of material examined, a justification for the identification and the literature employed. Descriptions are accompanied by comments on species ecological preferences drawn from this study and observations during fieldtrips across the Yucatán Peninsula in 2005 and 2008 (Pérez et al. 2009, 2010). 


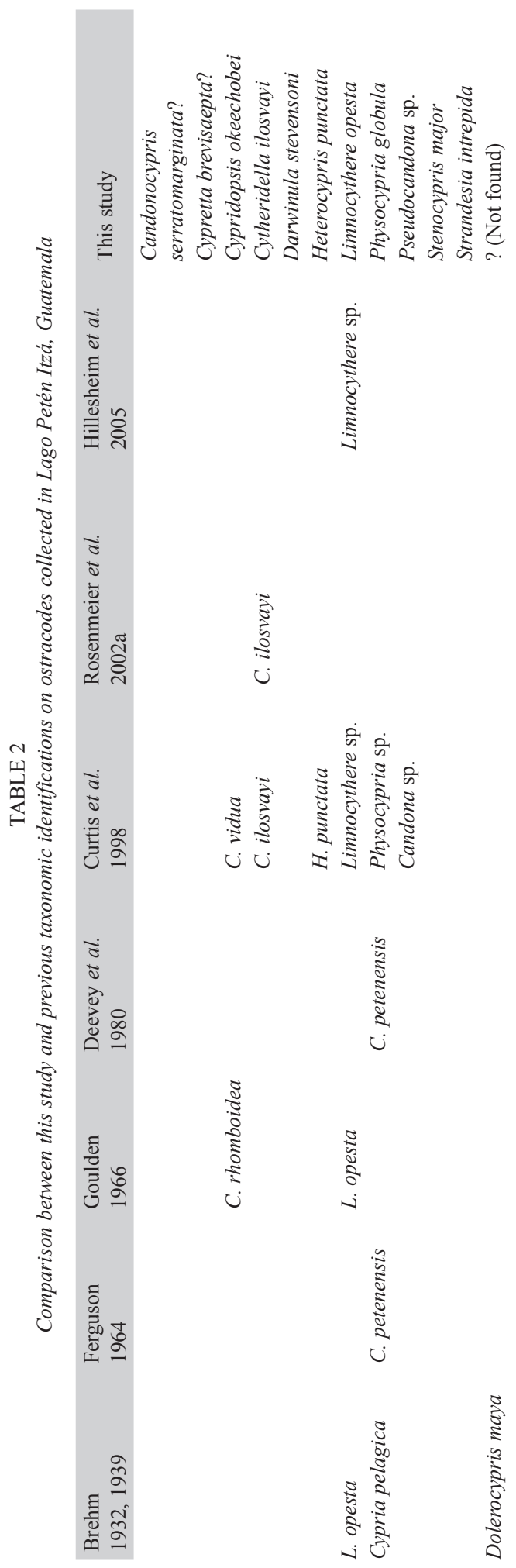

\section{Candonocypris serratomarginata?}

(Furtos, 1936)

(Fig. 2A)

*1936a Eucypris serrato-marginata n. sp. Furtos - Furtos: 107-108, Figs. 107-111.

1936b Candonocypris serrato-marginata (Furtos) - Furtos: Text 504, 505.

1947 Eucypris serrato-marginata, Candoncypris serrato-marginata (Furtos) - Tressler: Text 703.

Material: Only a few valves, mostly broken and all articulated, were found during our sampling campaigns. The analyzed material included surface sediment samples collected from shallow water $(0.5 \mathrm{~m})$ in a small tributary of Lago Petén Itzá (River Ixlú) and from shallow water in a littoral area on the west side of the lake (Fig. 1B).

Taxonomy: According to the International Commission on Zoological Nomenclature (ICZN), the valid species name is $C$. serratomarginata, omitting the hyphen used by Furtos (1936a). Samples we found probably belong to $C$. serratomarginata because the valves are elongated and serrated (denticulated) (see arrow, Fig. 2A). According to Furtos (1936a) the anterior and the posterior margins of both valves are serrated. The valves we collected presented serration only on the posterior margin, but all the other morphological characteristics reported by Furtos (1936a) coincide with ours. We collected only one right valve from a juvenile which presented a prominent spine at the posteroventral margin. The length of the valve is slightly less than two times the height. The greatest height is reached in the anterior third of the valve. The ventral margin of the valves is slightly curved, the anterior part of the valve is broad and rounded, and the posterior is narrower. The surface of the valves is smooth and contains sparse hairs (Furtos 1936a). The valves of our specimens seem similar to the genus Trajancypris described by Martens (1989) and the species Chlamydotheca unispinosa (Baird 1862). Ostracode valves collected by us seem to be the juveniles of the very 


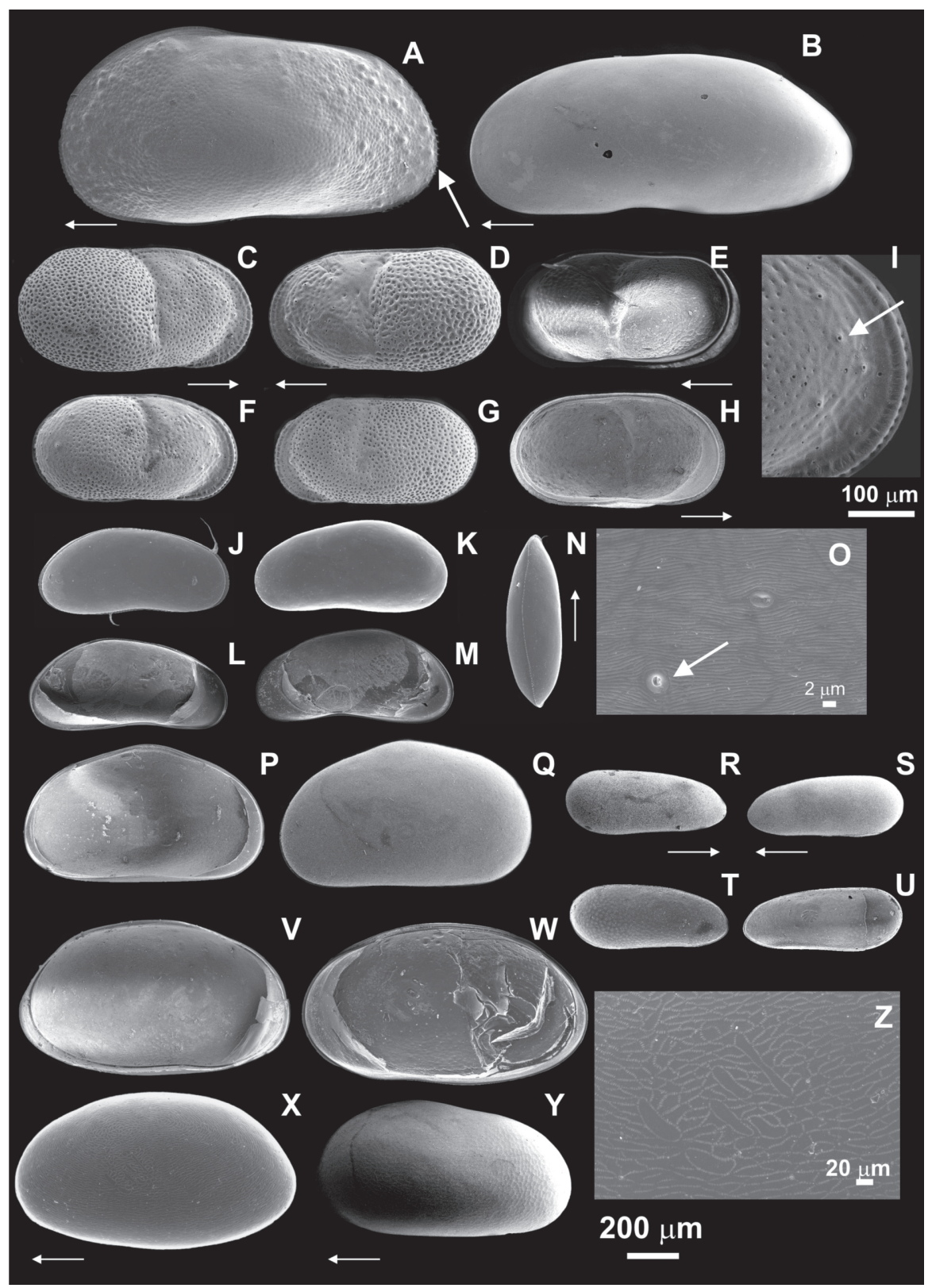

Fig. 2. The small arrows under the ostracode valves indicate the anterior or posterior side. Candonocypris serratomarginata? (A.) LV, external view. The arrow indicates the serration on the posterior margin; Stenocypris major (B.) Carapace left side, external view; Cytheridella ilosvayi. (C.) RV, external view, female; (D.) LV, external view, female; (E.) RV, internal view, female; (F.) RV, external view, male; (G.) LV, external view, male; (H.) LV, internal view, male; (I.) RV, external view, male, the arrow indicates the pores on RV, external view, male; Pseudocandona sp. (J.) Carapace, right side view, female; (K.) LV, external view, male; (L.) LV, internal view, male; (M.) RV, internal view, male; (N.) Carapace, dorsal view, female; (O.) Ornamentation of valve, external view, female, arrow indicates the pores on the LV; Heterocypris punctata (P.) LV, internal view, male; (Q.) LV, external view, male; Darwinula stevensoni. (R.) RV, external view, female; (S.) LV, external view, female; (T.) LV, internal view, female; (U.) RV, internal view, female; Strandesia intrepida. (V.) LV, internal view; (W.) $\mathrm{RV}$, internal view, male; (X.) LV, external view, male; (Y.) LV, external view, juvenile; (Z.) Ornamentation on left valve, external view. 
large ostracode C. unispinosa (Holmes 2010, pers. comm.). We need to collect more valves and carapaces with soft parts for a more accurate taxonomy. We did not find soft parts, and thus cannot provide descriptions. For detailed descriptions of $C$. serratomarginata appendages, see Furtos (1936a, b).

\section{Identification: Furtos 1936a, b.}

Size: The length of this species ranges from 1.71 to $2.05 \mathrm{~mm}$. Furtos (1936a) reported that females are $2.05 \mathrm{~mm}$ long and $1 \mathrm{~mm}$ high, and that no males were collected on the Yucatán Peninsula. A single specimen collected in Florida (Furtos 1936b) was only $1.71 \mathrm{~mm}$ long. In this study, only three specimens were collected, two left valves from an adult ostracode and one left valve from a juvenile (Table 1). Sizes reported in this study resemble those reported from Florida.

Biology, ecology, and geographic distribution: This species was reported by Furtos (1936a) in Xix Cenote, Valladolid, México. It has also been collected near Seminole City, Florida (Furtos 1936b). We also found it in a small pond in Belize, close to the coast. The species was collected in both calm and shallow running waters. Only females have been reported in the region (Furtos 1936a, b).

\section{Cypretta brevisaepta? Furtos, 1934}

(Fig. 3A, B)

*1934 Cypretta brevisaepta Furtos - Furtos: Text 283-284, Figs. 2a-h.

For synonymies see:

- Keyser 1976: Cypretta brevisaepta Furtos, 1934; C. brevisaepta brevisaepta Furtos sensu Furtos, 1936; C. nigra Furtos, 1936.

Material: Four articulated valves were recovered from sediments collected at water depths above the thermocline $(\sim 15 \mathrm{~m}$ water depth) in Lago Petén Itzá.
Taxonomy: The genus is very similar to Cypridopsis, but the row of septa along the anterior margin of each valve in Cypretta makes it possible to differentiate the two genera. When viewed from the side, valves are arched. The greatest height of the valve is reached in the middle. Anterior and posterior extremities are rounded, and the anterior is slightly broader. The ventral margin of the right valve is almost straight and the ventral margin of the right valve is slightly curved. The surface of the valves is smooth. All of the previous characteristics coincide with the descriptions of Furtos (1934, 1936b). We did not collect ostracodes with well-preserved soft parts. For detailed descriptions of C. brevisaepta appendages see Furtos (1936a, b).

Identification: Keyser 1976, Furtos 1934, 1936b.

Size: Furtos (1936b) reported females $0.85 \mathrm{~mm}$ long and $0.67 \mathrm{~mm}$ high. Males were slightly smaller than females, with lengths of $0.82 \mathrm{~mm}$, and heights of $0.60 \mathrm{~mm}$. We found specimens much smaller than the sizes reported by Furtos (1936b) (Table 1).

Biology, ecology, and geographic distribution: Species of this genus are known to have a nekto-benthic lifestyle. Reproduction of the genus is almost exclusively parthenogenetic, but there are exceptions (Furtos 1934). The genus is known to have a tropical and subtropical distribution, nevertheless a few species live in temperate climates (Sohn \& Kornicker 1972). Okubo (1973) reported the genus in Japan and Bronshtein (1947) reported it in Russia. The species $C$. brevisaepta is known from regions near the Yucatán Peninsula, southern Florida and the West Indies (Furtos 1934, Keyser 1976) and thus we believe that these individuals belong to this species. Nevertheless, we will need to analyze well-preserved soft parts from this species for a definitive identification. We present the first record for this genus in Guatemala. We found only a few valves in Lago Petén Itzá, thus we suspect that this species is not very abundant or may even be absent from the 


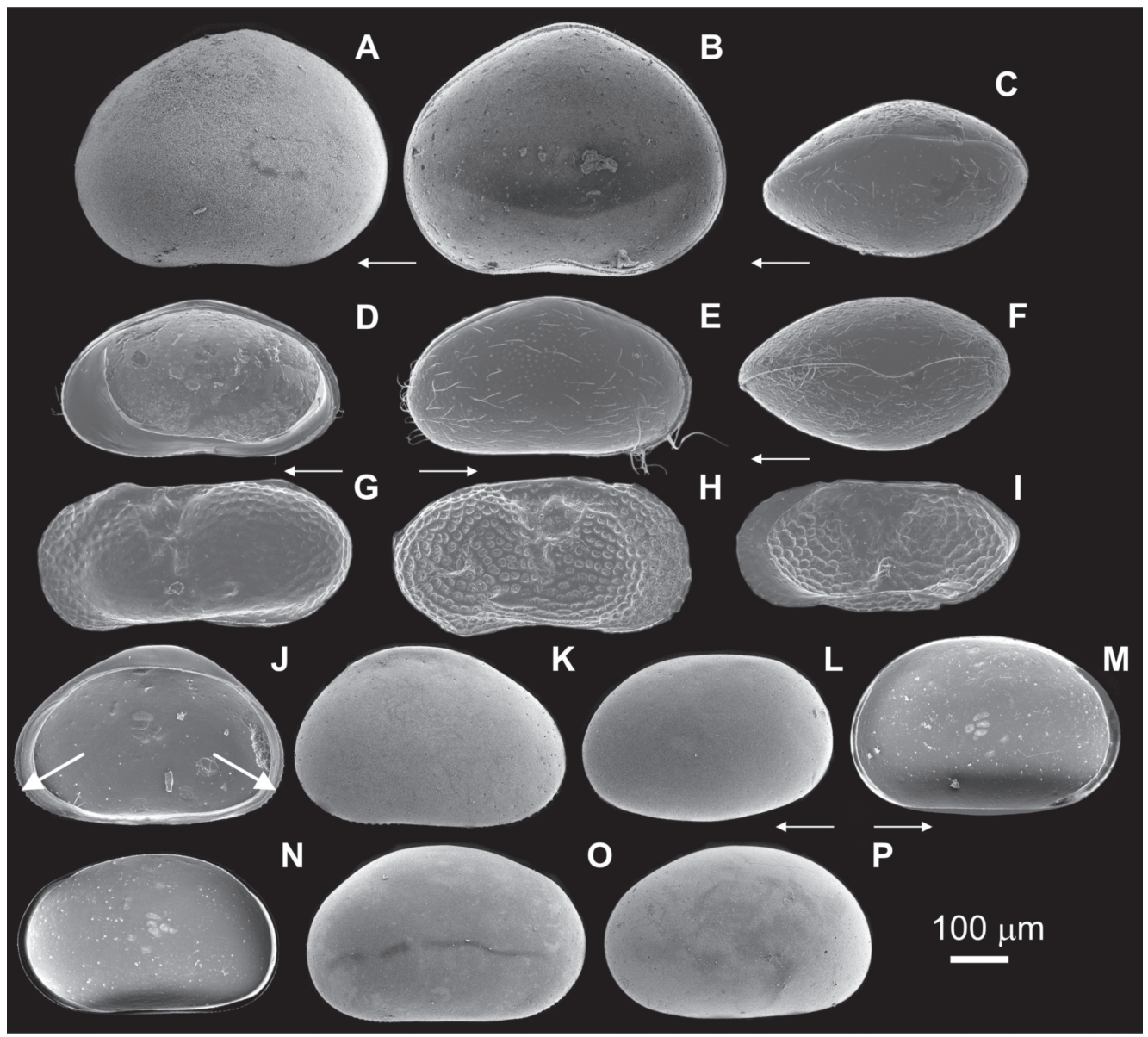

Fig. 3. The small arrows under the ostracode valves indicate the anterior or posterior side. Cypretta brevisaepta? (A.) Left valve (LV), external view; (B.) right valve (RV), internal view; Cypridopsis okeechobei (C.) Carapace, dorsal view; (D.) RV, internal view; (E.) Carapace right side, external view; (F.) Carapace, ventral view; Limnocythere opesta (G.) LV, external view, male; (H.) RV, external view, female; (I.) RV, internal view, female; Physocypria globula (J.) RV, internal view, female. The arrows show the pustules on the anterior and posterior margin; (K.) RV, external view, female; (L.) LV, external view, female; (M.) LV, internal view, female; (N.) RV, internal view, male; (O.) RV, external view, male; (P.) LV, external view, male.

lake. Two single valves were also collected in Lake Macanché, near Petén Itzá. We collected abundant living specimens of this species in Lake Oquevix, Petén, Guatemala in February. Water temperature in Lake Oquevix was relatively high $\left(31.4^{\circ} \mathrm{C}\right)$, and conductivity was low $(238 \mu \mathrm{S} / \mathrm{cm})$, showing the preference of the species for warm, low-conductivity waters.

\section{Cypridopsis okeechobei Furtos, 1936}

(Fig. 3C-F; Fig. 4A, B)

?1776 Cypris vidua Müller - Müller in Meisch 2000: 372-378, Figs. 155-156.

*1936b Cypridopsis okeechobei sp. nov. Furtos - Furtos: 492-493, Figs. 1a-i.

1966 Cypridopsis rhomboidea Furtos - Goulden: Text 107, 108. 


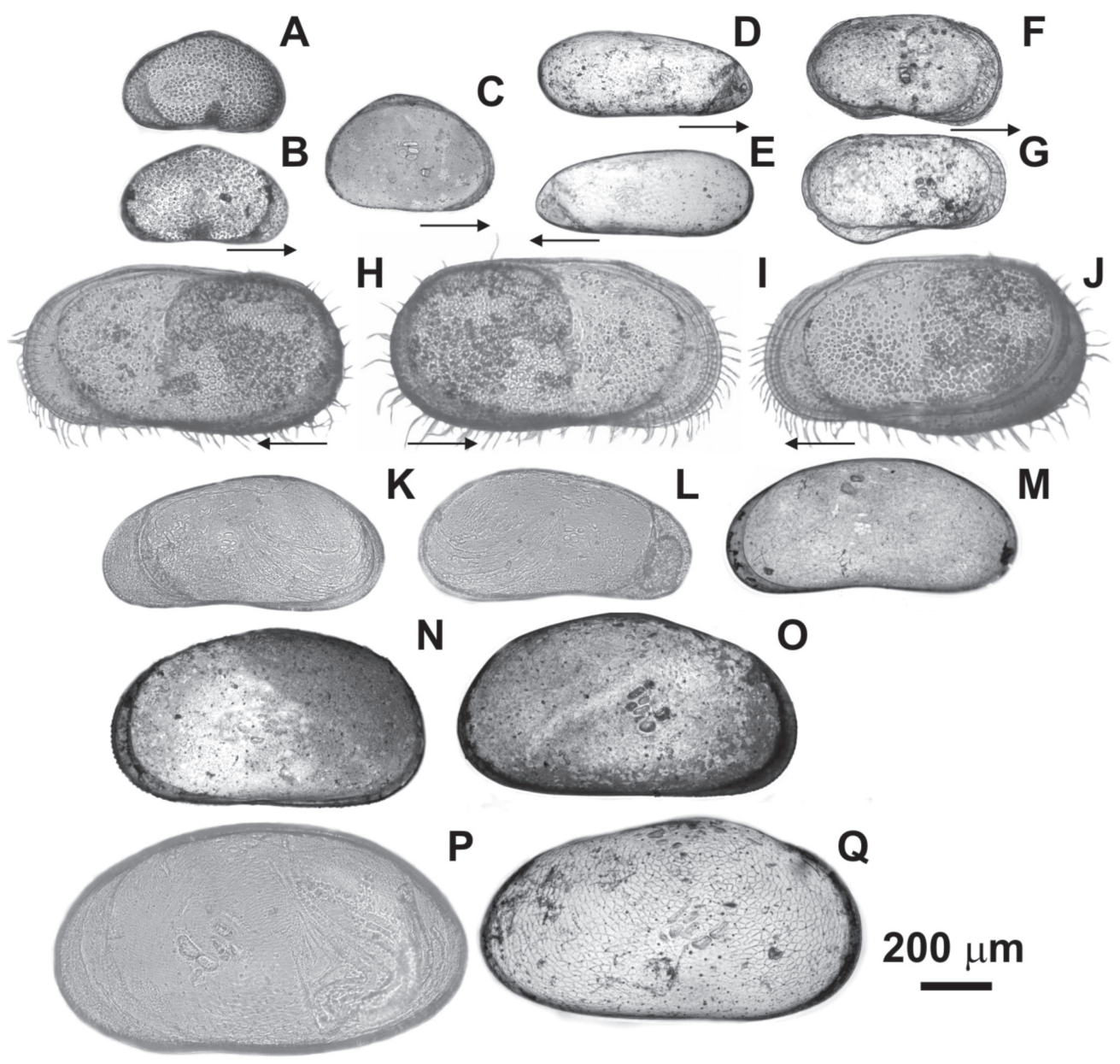

Fig. 4. Light microscope pictures. Cypridopsis okeechobei. (A.) RV, internal view; (B.) RV, external view; Physocypria globula (C.) RV, external view, female; Darwinula stevensoni (D.) RV, external view, female; (E.) LV, external view, female; Limnocythere opesta (F.) RV, external view, female; (G.) RV, external view, male; Cytheridella ilosvayi (H.) LV, external view, female; (I.) RV, external view, female; (J.) RV, internal view, female; Pseudocandona sp. (K.) LV, external view, male; (L.) RV, external view, male; (M.) RV, internal view; Heterocypris punctata (N.) LV, external view, female; (O.) RV, external view, male; Strandesia intrepida (P.) LV, external view, male; (Q.) RV, external view.

1998 Cypridopsis vidua Müller - Curtis et al.: Text 146, 152.

For synonymies of $C$. vidua see:

- Meisch 2000: Cypris vidua O. F. Müller, 1776, Cypris pincta Straus, 1821, Cypridopsis obesa Brady \& Robertson, 1869, ?Cypridopsis vidua concolor Daday, 1900, Cypridopsella helvetica Kaufmann, 1900, Cypridopsella tumida Kaufmann, 1900, Cypridopsis parva
Müller, 1900, Cypridopsis vidua f. obesa G. W. Müller, 1900, ?Cypridopsis concolor Müller, 1912, ?C. okeechobei Furtos, 1936, Cypridopsis mariae Rome, 1943, Cypridopsis parvoides J. M. Martens, 1977.

Material: We collected hundreds of articulated valves and carapaces containing or lacking soft parts, across the north-south surface 
sediment transect, covering a broad range of water depths in Lago Petén Itzá $(0.5-160 \mathrm{~m})$.

Taxonomy: The descriptions and drawings made by Furtos (1936b) are remarkably good, making identification easy. Further description of $C$. okeechobei appendages can be found in Furtos (1936b). This species displays similar morphological characteristics with Cypridopsis vidua, as both have hairy valves of similar shape, and similar appendage morphology. Meisch (2000) suggested that $C$. okeechobei could be a sexual form of $C$. vidua. Further analyses are needed to test this. This is why we included $C$. vidua in the synonymy list of C. okeechobei.

Identification: Furtos 1936b.

Size: The left valve is larger and encloses the right valve. Specimens collected by us are smaller than those reported by others (Table 1). Furtos (1936b) found females $0.64 \mathrm{~mm}$ long and $0.40 \mathrm{~mm}$ high. Males are smaller than females, or of similar size $(0.58 \mathrm{~mm}$ long and $0.37 \mathrm{~mm}$ high).

Biology, ecology, and geographic distribution: The species name comes from the lake where it was first collected, Lake Okeechobee, Florida, USA (Furtos 1936b). Keyser (1976) collected the same species in Florida. The species was thought be distributed only in the United States, but we noted its presence in almost all lakes and cenotes (sinkholes) sampled during our fieldtrips in 2005 and 2008 across the Yucatán Peninsula, including Izabal, Perdida, Macanché, Yaxhá (Guatemala), Almond Hill, Crooked Tree, and Honey Camp Lagoons, Cenote, a small un-named pond (Belize), and Milagros, Bacalar, Nohbec, Ocom, Punta Laguna and Yalahau (México). The species was also found in water with a conductivity of $5960 \mu \mathrm{S} / \mathrm{cm}$ and salinity of $3.2 \%$, showing it tolerates high dissolved ion concentrations. Keyser (1976) collected it in waters with salinity up to $4.3 \%$ and temperatures from 19 to $31^{\circ} \mathrm{C}$. Cypridopsis okeechobei is a nekto-benthic species. It is very abundant in the littoral zone of Lago Petén Itzá. Living ostracodes were collected in waters $<40 \mathrm{~m}$ deep. Similar to P. globula, C. okeechobei shows a broad hydrochemical tolerance. Keyser (1976) indicated its preference for calm waters. Cypridopsis okeechobei exhibits sexual reproduction and both females and males were present. Only female specimens of $C$. vidua have been collected (Meisch 2000). If C. okeechobei is, in fact, a sexual form of $C$. vidua, then the species has a world-wide distribution.

\section{Cytheridella ilosvayi Daday, 1905}

(Fig. 2C-I; Fig. 4H-J)

*1905 Cytheridella ilosvayi n. sp. Daday Daday: Text 262-267, Figs. 371, Plate 17, Fig. 15-28; plate 18, Fig. 1-11.

For synonymies see:

- Purper 1974: Cythereis ilosvayi (Daday) Müller, 1912; Cytheridella ilosvayi Daday, Klie, 1930; Onychocythere alosa Tressler, 1939, Metacypris? sp. Bold, 1958; Cytheridella sp. (Bold 1958) Pinto \& Sanguinetti, 1962; Cytheridella ilosvayi Daday, Pinto \& Sanguinetti, 1962; Metacypris ometepensis Swain \& Gilby, 1964.

- Martens \& Behen 1994: Metacypris ometepensis n. sp. Swain \& Gilby, 1965; Cytheridella ometepensis (Swain \& Gilby, 1965), Swain \& Gilby, 1970.

Material: We found several hundred articulated valves and fewer carapaces. Only a few ostracodes were found with well-preserved soft parts. Ostracodes were recovered from surface sediments collected across a north-south transect from the littoral zone to a maximum depth of $160 \mathrm{~m}$. We collected more valves in the northern part of the lake.

Taxonomy: The species is widely distributed throughout the American continent. It has thus been studied in great detail and there are abundant publications providing descriptions, drawings and photographs of valves, carapaces and soft parts (Löffler 1961, Purper 1974, Würdig 1983). 
Identification: Daday 1905.

Size: The species displays sexual dimorphism. Females are rounder and males are slightly smaller (Table 1).

Biology, ecology and geographic distribution: This species is primarily neotropical. It is distributed in South and Central America and the Caribbean islands; Brazil, Chile, Cuba, Nicaragua, Paraguay, Trinidad and Venezuela (Martens \& Behen 1994). We collected the species in other lakes of the Yucatán Peninsula as well: Perdida, Macanché, Yaxhá (Guatemala), Almond Hill and Crooked Tree Lagoons (Belize), and Milagros, Bacalar, Ocom, Chichancanab and Yalahau (México). We found that $C$. ilosvayi prefers waters with conductivity $<5960 \mu \mathrm{S} / \mathrm{cm}$ and salinity $<3.2 \%$, and tolerates relatively high concentrations of sulfate, up to $2300 \mathrm{mg} / \mathrm{L}$. The species was found in waters with temperatures $>20^{\circ} \mathrm{C}$ and was distributed in Lago Petén Itzá from the littoral zone to the base of the thermocline $(\sim 40 \mathrm{~m})$. Surface sediment samples collected in November 2005 from Lago Petén Itzá contained few carapaces of C. ilosvayi with soft parts. Instead, samples contained mainly valves, which were more abundant in the northern part of the lake. Samples retrieved in February and March 2008 had both carapaces and soft parts, mostly from females. It is a benthic species, and is more abundant in the lake's northern basin. Many living adult ostracodes were found in Lago Petén Itzá's Río Ixlú tributary, a small river with aquatic plants and slow current.

\section{Darwinula stevensoni (Brady \& Robertson, 1870)}

(Fig. 2R-U; Fig. 4D, E)

*1870 Polycheles stevensoni nov. sp. Brady \& Robertson - Brady \& Robertson: Text 25, 26, Plate 7, Figs. 1-7, Plate 10, Figs. 4-14.

For synonymies see:

- Furtos 1933: Argilloecia aurea plus Polycheles stevensoni Brady \& Robertson, 1870; Darwinella stevensoni Brady \& Robertson,
1872; Darwinula improvisa Turner, 1895; Darwinula aurea, G. W. Müller, 1912.

- Meisch 2000: Polycheles stevensoni Brady \& Robertson, 1870; Darwinula stevensoni nov. comb. Brady \& Robertson, 1885; D. improvisa Turner, 1895; D. protracta Rome, 1953; D. variabilis Tagliasacchi-Masala, 1968; D. sphenoides Rome, 1977.

Material: Hundreds of articulated valves and carapaces were recovered from surface sediments collected across a north-south transect from the littoral zone to a maximum depth of $160 \mathrm{~m}$. Highest concentrations of valves and carapaces were found in samples from the littoral zone to a water depth of $15 \mathrm{~m}$.

Taxonomy: There are many publications with good morphological descriptions of this taxon (Meisch 2000) because of the worldwide distribution of this species.

\section{Identification: Meisch 2000.}

Size: The right valve is larger than the left valve, and overlaps the left valve ventrally (Meisch 2000). No males were found in our samples (Table 1).

Biology, ecology and geographic distribution: Darwinula stevensoni is distributed on the American continent and has been collected in water bodies in Brazil, Nicaragua and the West Indies (Martens \& Behen 1994). We found it on the Yucatán Peninsula as well. It has a cosmopolitan distribution (Meisch 2000). There are reports of this species from Russia (Bronshtein 1988) and South Africa (Rossetti \& Martens 1996). It is widely distributed in aquatic environments in west and central Europe (Meisch 2000), Turkey (Furtos 1933), Kenya, Ethiopia, Congo (Martens \& Behen 1994), and Japan (Smith \& Kamiya 2008). We found this ostracode in most of the lakes we studied, but typically, it was not very abundant. Only a few living specimens were collected. Data from our field campaign in 2005 suggest that this species lives at water depths down to 
15m (Lago Petén Itzá and Izabal, Guatemala). It was more abundant in the shallow, southern basin of Lago Petén Itzá. Darwinula stevensoni is a benthic species that has also been reported from interstitial groundwaters (Meisch 2000). We found specimens in waters with conductivity up to $1715 \mu \mathrm{S} / \mathrm{cm}$ (Almond Hill Lagoon, Belize). The species, however, apparently is tolerant of mesohaline environments $(\leq 15 \%$ ) (Meisch 2000). Keyser (1976) found this species mostly in waters with salinity between 1 and $4 \%$, along with a few specimens in salinities of $\sim 13.5 \%$. Typical habitats are ponds, lakes and streams with slow currents (Meisch 2000). Rossetti \& Martens (1996) studied the morphological variability of hard and soft parts of this species in widely dispersed populations. Size seemed to be the only characteristic that varied between populations of different geographic and climatic regions.

\section{Heterocypris punctata Keyser, 1975}

(Fig. 2P, Q; Fig. 4N, O)

*1975 Heterocypris punctata Keyser-Keyser: Text 275-277, 290, Fig. 13, Plate 12, Figs. 10-11.

Material: Hundreds of articulated valves and carapaces without soft parts were encountered. Specimens were found only in surface sediments from the shallow $(<1 \mathrm{~m}$ water depth) southern littoral zone of Lago Petén Itzá. No carapaces with well-preserved soft parts were collected.

Taxonomy: This species has been reported from southwest Florida. Keyser (1975) described this species and presented drawings of soft parts and valves, along with SEM photos.

\section{Identification: Keyser 1975.}

Size: The left valve is longer, and encloses the right valve. We found mostly juveniles, but also a few adults. Females are bigger than males and we found mostly males in our samples (Table 1).
Biology, ecology, and geographic distribution: Before our field trip in 2005, this species was reported only from Marco Island, Florida, USA (Keyser 1975), and Lake Pátzcuaro in central México (Bridgwater et al. 1999). Living ostracodes were collected in Lago Petén Itzá among macrophytes, at $0.1 \mathrm{~m}$ and $0.7 \mathrm{~m}$ water depth in the southern basin. The substrate was composed of silty detritus. Ostracodes sampled by Keyser (1975) were also found in very shallow water, about $0.1 \mathrm{~m}$ deep. This shows its potential as an indicator of water depth. It is a nekto-benthic species. We did not find abundant valves or carapaces with soft parts during either field campaign. Heterocypris punctata prefers calm waters with salinities up to $10 \%$, and is mostly found in sediment and organic detritus (Keyser 1975).

\section{Limnocythere opesta Brehm, 1939}

(Fig. 3G-I; Fig. 4F, G)

*1939 Limnocythere opesta n. sp. Brehm Brehm: Text 178-179, Plate 35, Fig. 8; Plate 36, Fig. 9.

1998 Limnocythere sp. - Curtis et al.: Text 146, 152.

2005 Limnocythere sp. - Hillesheim et al.: Text $367,369,372$.

Material: We found several hundred articulated valves and carapaces with and without soft parts. Specimens were found from the littoral zone to a maximum water depth of $160 \mathrm{~m}$. Living specimens with well-preserved soft parts were collected mainly from the littoral zone to a water depth of $15 \mathrm{~m}$.

Taxonomy: This species was collected and identified as Limnocythere sp. in 1932 (Brehm 1932). In 1939, Brehm identified it as a new species and gave it the name Limnocythere opesta. He made a first description of this species based on a female specimen, and thus a description of the male and female copulatory organs is lacking. Sexual dimorphism is seen in this species in the valve morphology. The posterior margin of the male valve is round (Fig. $4 \mathrm{G})$, while female valves possess a triangular 
shape (Fig. 4F). The dorsal margin in females is almost straight. The valve surface is reticulated and possesses round pits. The right and left valves of females and males possess a spine or protuberance on the posterior area. Females are smaller than males and carapaces of males are longer than those of females. Valves are elongated when seen from the lateral side. The carapace has a beak-shaped anterior end in dorsal view. The left valve overlaps the right valve at the posterior end. This species is characterized by unbranched pore canals on the anterior and posterior margins of the valves. Valves possess a dorsomedian-sulcus. Two tubercles are seen on both valves. Valves have four adductor scars arranged in a vertical row. The third walking leg is longer than the first and second. The first walking leg has two knee-setae, while the second and third walking legs have only one knee seta. The middle part of the basal segment of the three walking legs has a posterior seta. The uropod is distally tapering, and its flagellum is about the same size as the uropodal ramus.

At first glance, Limnocythere floridensis Keyser, 1976 is very similar to L. opesta. The elongated distal lobe of the penis of L. opesta allows distinguishing between these species.

Identification: Brehm 1939.

Size: Males are longer than females. The posterior part of the valve is big and round in males, and smaller in females (Table 1).

Biology, ecology, and geographic distribution: Limnocythere opesta was first collected in Lago Petén Itzá, and we collected it in nearby lakes around the Yucatán Peninsula. Goulden (1966) reported L. opesta in Lake Petenxil, near Lago Petén Itzá. We found that $L$. opesta tolerates water with conductivities $\leq 5960 \mu \mathrm{S} / \mathrm{cm}$ and sulfate concentrations $\leq 2300 \mathrm{mg} / \mathrm{L}$, similar to C. ilosvayi. This species was collected by Dampf in 1925 (Brehm 1939), but only in shallow waters between Equisetum plants. In November 2005 we found abundant male and female adults with soft parts, from shallow waters to a maximum depth of $\sim 40 \mathrm{~m}$, i.e. about the base of the thermocline in Lago Petén Itzá. This is a benthic species that is more abundant in the northern part of the lake. Valves and empty carapaces were found in water depths down to $160 \mathrm{~m}$, but could have been transported by currents. In February and March 2008 we found few adult ostracodes with soft parts in the River Ixlú and in the littoral zone on the west side of the lake. Samples contained primarily valves and a few empty carapaces. Abundant living specimens were collected in November 2005, at the end of the rainy season, among macrophytes in the littoral zone. Further investigations on the seasonality of this species are necessary. Limnocythere opesta may be endemic to the Yucatán Peninsula.

\section{Physocypria globula Furtos, 1933}

(Fig. 3J-P; Fig. 4C)

*1933 Physocypria globula n. sp. Furtos Furtos: Text 468-469, Figs. 522-523, Plate 16, Figs. 1-9.

1932 Cypria pelagica, n. sp. Brehm - Brehm: Text 65.

1939 Cypria pelagica, n. sp. Brehm - Brehm: Text 180, Plate 36, Figs. 13-15.

1964 Cypria petenensis n. sp. Ferguson et al. Ferguson et al.: Text 1-4, Figs. 1-6. 1998 Physocypria sp. - Curtis et al.

Material: We retrieved several hundred articulated valves and carapaces with and without soft parts. The highest abundance of valves was found at a water depth of $50 \mathrm{~m}$. More living specimens were collected on the southern shore of the lake. Specimens were also collected in deep waters $(50-160 \mathrm{~m})$.

Taxonomy: We discovered that the species was erroneously described as Cypria petenensis, and propose that is a member of the genus Physocypria. According to Meisch (2000) the principal difference between Cypria and Physocypria is that Cypria lacks the small pustules on the posterior and anterior margins of the right valve that Physocypria possesses. Male and female specimens we collected in Lago 
Petén Itzá and other regional lakes have small pustules on the posterior and anterior margins of the right valve (Fig. 3J), which are absent in the middle. We sampled intensively at different water depths along the N-S surface sediment transect and at various sites in the littoral zone of Lago Petén Itzá, but found no individuals belonging to the genus Cypria. We are therefore confident that Cypria does not inhabit this water body. Ferguson et al. (1964) might have overlooked the small pustules on the margin of the right valve. To test this, we requested five good specimens of $C$. petenensis from the Natural History Museum in London, which had been collected by Deevey in 1961 (Ferguson et al. 1964) at Lago Petén Itzá. After studying the valves and soft parts under the stereoscope and microscope, it was apparent the individuals belonged to the genus Physocypria. Our specimens and the ones collected by Deevey possess a long distal 'e' seta on the second segment of the walking leg, as well as pustules on the posterior and anterior margins of the right valve, as described for the genus Physocypria (Meisch 2000). Physocypria globula was described by Furtos in 1933, before C. petenensis (1964), thus the correct species name is $P$. globula. The carapace is subovate when viewed from the side. Valves are thin and not well calcified. The anterior and posterior margins are rounded and the anterior margin is narrower. The margin of the left valve is smooth, and lacks pustules. Some specimens have a dorsal "hump-like" flange on the right valve, primarily in females. Prehensile palps are unequal, and the penis is triangular, with two terminal lobes that are bent at the tip (Furtos 1933).

\section{Identification: Furtos 1933}

Size: Females are normally bigger than males, or of similar size (Furtos 1933). The left valve is longer than the right valve (Table 1). Ostracodes collected by us are smaller than those reported in the literature.

Biology, ecology and geographic distribution: Physocypria globula was first collected in Ohio (Buckeye Lake, Bass Lake, Cleveland Lake, Snow Lake, Geauga Lake, Chardon and North Bass Island) by Furtos (1933). We collected this species in the Guatemalan highlands and lowlands. According to Furtos, this species is very common in ponds and small lakes and was mostly found from March to October. Living specimens were collected in November 2005 in Lago Petén Itzá from the littoral zone down to a depth of about $60 \mathrm{~m}$, i.e. below the thermocline. Physocypria globula is the most abundant species in Lago Petén Itzá and was found in all surface sediment samples. This ostracode is distributed in the Petén Lake District and other lakes of the Yucatán Peninsula (Deevey et al. 1980). Physocypria globula shows a preference for deep waters, and has a tolerance for waters with low oxygen concentration $(\sim 3 \mathrm{mg} / \mathrm{L})$. The species is known to be a nekto-benthic ostracode, and our sampling in the region showed that it displays a wide hydrochemical tolerance. In 1973 and 1974, Deevey et al. (1980) analyzed seasonal variations and vertical migrations of ostracode populations in Petén lakes. They found that in August, $P$. globula numbers are minimal. Deevey et al. (1980) reported that $P$. globula is one of the few freshwater planktonic species in the world. This ostracode demonstrates vertical migration. Recruitment of P. globula in Lake Yaxhá seems to occur in December and January. Alvarez Zarikian et al. (2005) and Willard et al. 2007 indicate that $P$. globula has a broad biogeographic distribution and a high hydrochemical tolerance, but seems to prefer warm water temperatures $\left(18-20^{\circ} \mathrm{C}\right)$ and thus is very abundant in sediments deposited in the early interglacial warm periods. This species inhabits fresh to slightly saline aquatic environments (total dissolved solids $<10,000 \mathrm{mg} / \mathrm{L}$, Alvarez Zarikian et al. 2005).

\section{Pseudocandona sp.}

(Fig. 2J-O; Fig. 4K-M)

1998 Candona sp. - Curtis et al.: Text 143, 146, 147, 149, 150, 152, 153.

Material: We found hundreds of articulated valves, as well as carapaces with and 
without soft parts. Ostracodes were collected from surface sediment samples collected at several water depths in Lago Petén Itzá. The material was mainly composed of valves. The highest number of carapaces was found in the littoral zone to a water depth of $15 \mathrm{~m}$.

Taxonomy: We identified our specimens as Pseudocandona sp. because the basal segment of the cleaning leg has three setae, one of which is short and two of which are long. When seen from the ventral side, the left valve overlaps the right valve. The surface of the valve has perpendicular attached setae, but is not densely covered. The ventral margin of the valve is curved. The surface of the valve is smooth (Fig. 2O). The externo-distal seta on the penultimate segment of the mandibular palp is smooth. The genital lobe is rounded and slightly protruding. The right clasping organ in males is bigger than the left clasping organ. The uropodal claws are long, proximally straight and distally curved. The Zenker organ presents $5+2$ rings of spines. All of these characteristics coincide with those indicated by Meisch (2000) for the genus Pseudocandona. On first seeing the valve, the initial impression was that its shape and size were similar to Candona annae collected by Keyser (1976) in southwest Florida, USA. The genus Candona presents only two setae on the basal segment of the cleaning leg. Pseudocandona together with Candona, has a large number of described species, making it difficult to distinguish our specimens from previously described species. There is no literature reporting Pseudocandona sp. from the Yucatán Peninsula, but it is possible that the present species was first identified as Candona. We believe the first report of this species in Lago Petén Itzá, and in Guatemala, was that of Curtis et al. (1998). In that publication they only mentioned the existence of this species in Lago Petén Itzá. We found only a few living specimens for soft part preparation.

Identification: Meisch 2000.
Size: Males are higher and longer than females. The left valve is bigger than the right valve (Table 1).

Biology, ecology and geographic distribution: This species has a wide distribution in the Yucatán Peninsula. In 2005 we collected specimens in the following lakes: Perdida, Macanché, Yaxhá (Guatemala), Crooked Tree and Honey Camp Lagoons and a small unnamed pond (Belize), and Milagros, Bacalar, Nohbec, Ocom, Punta Laguna and Yalahau (México). It is a benthic species and we collected it mostly from sediments with high organic content. It was more abundant in shallow waters $(<40 \mathrm{~m})$. We found that Pseudocandona sp. tolerates conductivity up to $1715 \mu \mathrm{S} / \mathrm{cm}$. Valves of this species were found at different water depths across the N-S transect in Lago Petén Itzá. The genus is distributed throughout Europe, Asia, Siberia, and North America (Meisch 2000).

\section{Stenocypris major (Baird, 1859)}

(Fig. 2B)

*1859 Cypris cylindrica Sowerby var. major Baird - Baird: 233, Plate 63, Fig. 4.

1886 Stenocypris malcolmsoni Brady - Brady: 297, Plate 18, Figs. 5-7.

1889 Stenocypris malcolmsonii (Brady) - Sars: 1-79, Plate 1, Figs. 7, 8, Plate 5, Figs. 1-4.

1898 Stenocypris major Daday - Daday: 69, Fig. 34

1947 Stenocypris malcolmsoni (Brady) Tressler: 704.

2001 Stenocypris major Daday - Martens: 295308.

For synonymies see:

- Martens \& Behen 1994: Stenocypris cylindrica major (Baird, 1859), Stenocypris malcolmsoni (Brady, 1886) Sars, 1889, Cypris chittyensis Baird, 1862 nov. syn.

- Martens 2001: Stenocypris malcolmsoni (Brady, 1886). 
Material: Two articulated valves were collected in the small tributary of Lago Petén Itzá, the River Ixlú.

Taxonomy: This species has been studied in considerable detail (Furtos 1936a, Klie 1939, Brehm 1949, Würdig 1983).

\section{Identification: Furtos 1936a.}

Size: Only two valves of this species were found in all collected surface sediment samples, thus we could not determine the sex of the ostracodes (Table 1). Furtos (1936a) collected only females in a study of cenotes in Yucatán.

Biology, ecology, and geographic distribution: The species is widely distributed. We have also collected $S$. major in Lake Izabal (Guatemala), and in a small pond in Belize. There we found only a few specimens, including living specimens with soft parts. Because of the very low number of collected valves, it is possible that this species was transported to the lake. The species has a world-wide distribution (Furtos 1936a, Martens \& Behen 1994). Some sites where it has been collected include Mérida, Champotón, and Campeche (México) (Furtos 1936a), Brazil and the West Indies (Martens \& Behen 1994), India, Sri Lanka, Australia, East Africa (Furtos 1936a), Japan (Smith \& Kamiya 2006), and the Pacific Islands (Meisch et al. 2007). It is a nekto-benthic species. Sars (1889) reported that this species is exclusively parthenogenetic. He studied its life cycle and found abundant specimens during summer to late summer.

\section{Strandesia intrepida Furtos, 1936}

(Fig. 2V-Z; Fig. 4P, Q)

*1936a Strandesia intrepida n. sp. Furtos - Furtos: Text 111, 108, Figs. 112, 113; 109, Figs. 118-123.

?1939 Dolerocypris maya n. sp. Brehm Brehm: Text 179, Plate 36, Figs. 10-12.

1947 Strandesia intrepida Furtos - Tressler: Text 703.
Material: Few articulated valves and carapaces without soft parts were retrieved mainly from the littoral zone to a maximum water depth of $30 \mathrm{~m}$ in Lago Petén Itzá. More specimens were found in surface sediments from the northern part of the lake.

Taxonomy: S. intrepida was first described by Furtos (1936a), who provided a very good morphological description, accompanied by drawings of soft parts and valves.

\section{Identification: Furtos 1936a.}

Size: Only one male with soft parts was found and measured. The left valve is longer than the right valve. Only a few valves were found in surface sediments, thus we are uncertain of the sex of these measured ostracodes. They might belong to females, because valves are slightly bigger than the male we found. Furtos (1936a) collected females with a length of $1.76 \mathrm{~mm}$ and a height of $0.98 \mathrm{~mm}$. Males were smaller than females, or of similar size ( $1.50 \mathrm{~mm}$ high, $0.83 \mathrm{~mm}$ long). Specimens collected by us were generally smaller (Table 1).

Biology, ecology, and geographic distribution: Strandesia intrepida was found only in shallow waters $(<15 \mathrm{~m})$ of Lago Petén Itzá. This is a nekto-benthic species. No valves were found in waters $>15 \mathrm{~m}$. This shows the high potential of this species in paleolimnological studies and environmental reconstructions as an indicator of shallow waters above the thermocline $(<40 \mathrm{~m})$, just like $H$. punctata. We found this species in some lakes close to Lago Petén Itzá and in other lakes on the Yucatán Peninsula, including Lake Chichancanab (México), which displays very high sulfate concentration (2300mg/L).

\section{DISCUSSION}

Ostracode zoogeography: The ostracode community from Lago Petén Itzá contains mostly neotropical species, two nearctic species and two widely distributed species. Darwinula 
stevensoni and Stenocypris major are the only two species with a wide geographic distribution, and are known to be eurytopic species, i.e. taxa with a broad tolerance for ecological conditions. Species distributed only in the Yucatán Peninsula (Guatemala, México and Belize) are Limnocythere opesta, Strandesia intrepida, and Candonocypris serratomarginata?. There is still a need to collect living specimens of Cypretta brevisaepta? and $C$. serratomarginata? to confirm their identification. Heterocypris punctata is known to be distributed in Florida and México and it was reported from Lago Petén Itzá for the first time by Curtis et al. (1998). Cytheridella ilosvayi is a typical neotropical species, distributed from South America to Central America and México. Cypridopsis okeechobei, and Physocypria globula were known to be distributed primarily in North America, and here we document their presence at lower latitudes. Specimens of $C$. okeechobei were first collected by Goulden (1966) in sediments from the littoral zone of Lago Petén Itzá, but they were identified as $C$. rhomboidea. Studies from other Central American lakes are needed to establish if this species is also distributed in lower latitudes.

Ostracode taxonomy: We corrected a misidentification of $P$. globula in the lowland Neotropics. Specimens collected in the lake by Deevey in 1961 were thought to be endemic to the Petén lake District (Ferguson et al. 1964). We compared those specimens with ours and concluded that all specimens belong to the genus Physocypria. This species was first described by Furtos (1933) years before Ferguson et al. (1964). The valid name is thus Physocypria globula. Brehm (1939) described L. opesta as a new species for Lago Petén Itzá. Observations from two fieldtrips across the Yucatán Peninsula revealed that L. opesta is restricted to lakes near Lago Petén Itzá. Brehm (1939) also reported the presence of Dolerocypris maya. After intensive sampling in Lago Petén Itzá we did not find D. maya, which may indicate that the species is extinct in the lake, that it was misidentified, or that we simply failed to collect it. Two short cores $(\sim 40 \mathrm{~cm}$ long) at 10 and $40 \mathrm{~m}$ water depth and a long ( 70m) core (PI-6) retrieved by the Petén Itzá Scientific Drilling Project from Lago Petén Itzá do not contain remains of this species either. Brehm (1939) included drawings and a description of only one female. His descriptions of the valve shape, furcal ramus, and the cleaning leg are very similar to descriptions of $S$. intrepida by Furtos (1936a). It is possible that one of the species is misidentified, but we must inspect the original specimens to determine who is correct.

We found Cypridopsis vidua in Lake Izabal, and $C$. okeechobei in Lago Petén Itzá. Valve morphology of the two taxa is very similar. Cypridopsis okeechobei has both males and females, while $C$. vidua is known to be parthenogenetic. It is still unclear if $C$. okeechobei is a sexual form of $C$. vidua as suggested by Meisch (2000). Genetic analyses are needed to discern the affinities of the two species. Cywinska \& Hebert (2002) indicated that there is a possibility that $C$. vidua may be a recent asexual species that had a sexual ancestor. However, Furtos (1936b) indicated morphological characteristics that allow one to distinguish between the species. When viewed from above, $C$. vidua seems to be more tumid than C. okeechobei. Furthermore, the claw of the cleaning leg in C. vidua is smaller, and the species lacks males. Both species belong to the same genus, but they seem to have different ecological preferences. Cypridopsis vidua has a world-wide distribution, and can tolerate salinities higher than $4 \%$, while C. okeechobei is distributed only in North America and the Yucatán Peninsula, is restricted to salinities $<4 \%$, but has a limited temperature range, from 19 to $31^{\circ} \mathrm{C}$ (Keyser 1976). The different ecologies of these similar taxa illustrate the importance of correct identification if these organisms are to be used as bio-indicators or in paleolimnological studies.

Only a few living Pseudocandona sp. with well-preserved soft parts were collected, insufficient numbers to identify to species level. Nevertheless, we are certain that the collected 
individuals belong to the genus. We believe that this is a new species, endemic to the Yucatán Peninsula. Taxa with uncertain identification are Cypretta brevisaepta? and Candonocypris serratomarginata?, because their remains were rare and their soft parts were absent. To identify these specimens, soft parts, primarily from adults, are needed. This illustrates the need to sample other locations in the lake across different seasons.

Ostracode ecology and biology: The ecology and spatial distribution of ostracodes from Lago Petén Itzá are discussed in more detail in Pérez et al. (2010). The depth distribution of living ostracodes, from the littoral zone to $160 \mathrm{~m}$ water depth is shown along with the vertical temperature and dissolved oxygen profiles measured at the deepest point in the lake in November 2005 (Fig. 5).

Living adult ostracodes were primarily found in the littoral zone, which provides shelter, protection against predation, and high food availability. Heterocypris punctata and S. intrepida are species restricted to the littoral zone and live among abundant macrophytes. Valves were not found deeper than $15 \mathrm{~m}$, which indicates their restricted distribution in the lake, and limited transport by currents. They are associated with warm water temperatures and high dissolved oxygen concentrations. This makes both species good indicators of the littoral zone. Darwinula stevensoni prefers calm waters $<15 \mathrm{~m}$ deep, and was thus more abundant in the southern part of the lake. The southern basin of Lago Petén Itzá is shallower than the northern basin, and offers larger macrophyte cover and calmer waters. Cypretta brevisaepta? was also collected only in water $<15 \mathrm{~m}$ deep (Section I, Fig. 5). Live specimens of $L$. opesta, C. ilosvayi, Pseudocandona sp., and C. okeechobei were collected at water depths $<40 \mathrm{~m}$ (Section II, Fig. 5). Cytheridella ilosvayi and $L$. opesta were more abundant in the deep and steep-sloped northern basin at water depths to $40 \mathrm{~m}$, marking the base of the thermocline. Valves of Pseudocandona sp., P. globula and C. okeechobei were collected at different water

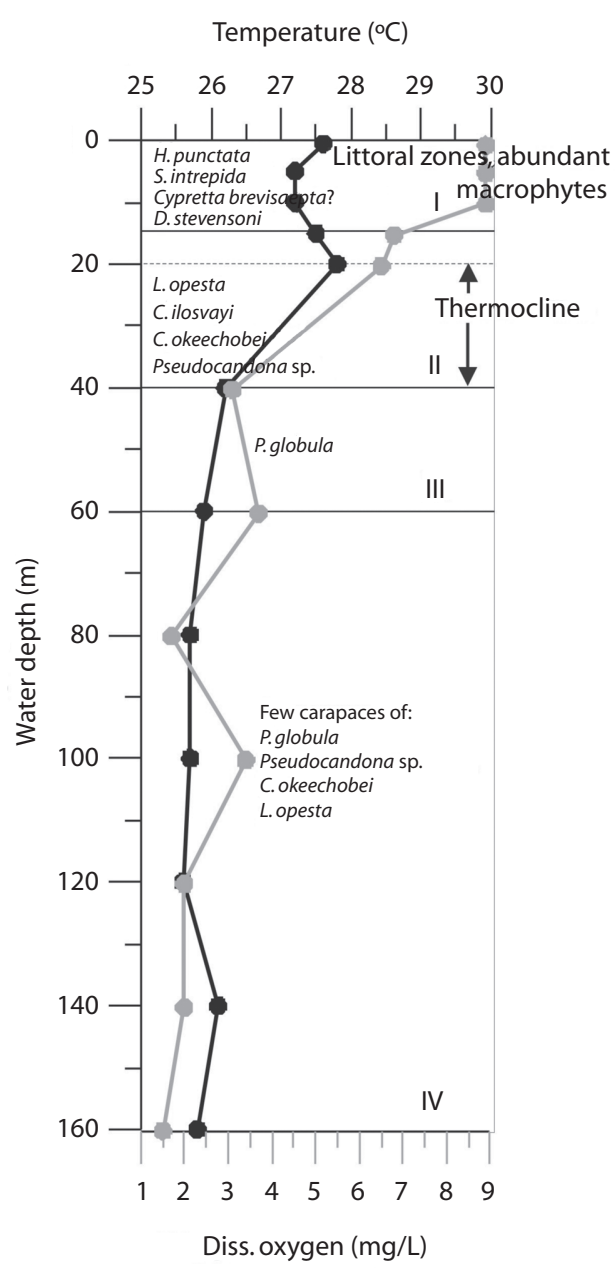

Fig. 5. Vertical distribution of living ostracodes from Lago Petén Itzá showing the species distributed in water depths $<15 \mathrm{~m}$ (section I), $<40 \mathrm{~m}$ (section II), $<60 \mathrm{~m}$ (section III), $<160 \mathrm{~m}$ (section IV) and their relationship with a temperature and a dissolved oxygen profile determined at the deepest point of the lake in November 2005.

depths in the northern and southern part of the lake. Physocypria globula has a tolerance for waters with low dissolved oxygen (this study). Live specimens were collected from the littoral zone down to a water depth of $60 \mathrm{~m}$ (Section III, Fig. 5). Few to no carapaces with soft parts were collected at water depths $>60 \mathrm{~m}$ (Section IV, Fig. 5), and were probably transported by currents. P. globula seems to be more abundant 
in warm waters and is thus more abundant in the Guatemalan lowlands than in the highlands. Stenocypris major and C. serratomarginata? prefer shallow, running waters, and thus were collected only in the Río Ixlú tributary and the western littoral zone of the lake. We cannot provide further information about the ecological preferences of Cypretta brevisaepta? and $C$. serratomarginata? because only single valves were collected and no living specimens were encountered. Sometimes we were unable to find both males and females with well-preserved soft parts, but information was compiled from the literature. The ostracode species display mainly sexual reproduction, with only one being parthenogenetic (D. stevensoni). In most cases, the ostracodes collected in this study were smaller than those described in the literature. This may be a consequence of the short life cycle of individuals in tropical environments, and hence, smaller size. Ostracodes have been collected, identified and studied in Lago Petén Itzá since 1925, yet there remained inconsistencies regarding their taxonomy. This lake is of great interest for paleolimnologists, due to the fact that it possesses a sediment record extending back in time $>200000$ years, perhaps the longest lake record from the lowland Neotropics. Lake Petén Itzá displays seasonal variability in the geochemistry of its waters, as well as dramatic lake level changes over longer timescales (Hillesheim et al. 2005). This could be one reason why this large lake does not possess many ostracode species. Considering that the lake has existed continuously for more than 200000 years, diversity might be expected to be high, as in other ancient lakes of the world (e.g. Lake Ohrid) (Albrecht \& Wilke 2008). Ostracodes are abundant in the sediments from Lago Petén Itzá and will be used to study past climate and environmental changes in the region. This study will contribute to accurate identification of ostracode remains, thereby enabling better paleoenvironmental inferences derived from fossil ostracode assemblages.

\section{ACKNOWLEDGMENTS}

We thank Dietmar Keyser (Zoological Museum, Hamburg, Germany) for taking the SEM pictures, Raúl Calderón for his assistance making the maps, Evgenia Vinogradova, Wolfgang Riss and Rita Bugja for their help during the field campaigns of 2005 and 2008, Margarita Palmieri, Margaret Dix, Roberto Moreno and Eleonor de Tott (Universidad del Valle de Guatemala, Guatemala), David Hodell (University of Cambridge, UK), and the Deutsche Forschungsgemeinschaft (DFG), which kindly provided funding (Grant Schw 671/3). We are grateful for the comments of Claudia Wrozyna, Peter Frenzel and Douglas Schnurrenberger, who helped to improve the manuscript.

\section{RESUMEN}

La taxonomía de los ostrácodos ha sido de gran interés debido a su posible uso como especies indicadoras de cambios del clima y de los ecosistemas. En América Central y del Sur se han llevado a cabo pocos estudios. Once especies de ostrácodos fueron colectadas en el 2005 y 2008 en el Lago Petén Itzá $\left(\sim 100 \mathrm{~km}^{2}\right)$, el segundo lago más grande de Guatemala y en su afluente, el Río Ixlú. Veintisiete muestras de sedimentos superficiales fueron extraídas a diferentes profundidades desde la zona litoral hasta la profundidad máxima $(160 \mathrm{~m})$ del lago. Partes duras y blandas de los ostracódos colectados fueron analizadas. Este estudio describe cada especie de ostrácodo con respecto a su taxonomía, tamaño, ecología, biología y distribución geográfica. Especies reportadas incluyen: Candonocypris serratomarginata?, Cypretta brevisaepta?, Cypridopsis okeechobei, Cytheridella ilosvayi, Darwinula stevensoni, Heterocypris punctata, Limnocythere opesta, Physocypria globula, Pseudocandona sp., Stenocypris major y Strandesia intrepida. La mayoría de las especies poseen una distribución neotropical, dos tienen una distribución mundial (D. stevensoni and $S$. major) y $C$. okeechobei y $P$. globula tienen una distribución neártica y neotropical. Presentamos un nuevo récord de C. brevisaepta?, C. serratomarginata?, S. major y $S$. intrepida para Guatemala. Physocypria globula fue identificada erróneamente en el Lago Petén Itzá como Cypria petenensis, Pseudocandona sp. había sido identificada como Candona sp. y C. okeechobei como C. vidua. Limnocythere opesta es una especie endémica de la región. Las especies más abundantes y de mayor distribución en el lago son P. globula, 
C. okeechobei y Pseudocandona sp. Especies restringidas a zonas litorales y aguas con una pronfundidad $<15 \mathrm{~m}$ son: D. stevensoni, $H$. punctata y $S$. intrepida. Limnocythere opesta y C. ilosvayi están distribuidas de la zona litoral a una profundidad de $40 \mathrm{~m}$. Especies recolectadas solamente en el afluente Ixlú y en la zona litoral oeste, fueron $C$. serratomarginata? y $S$. major. En general, los ostrácodos adultos identificados fueron más pequeños que los tamaños reportados en la literatura. Una correcta taxonomía mejorará el uso de las comunidades de ostrácodos fósiles de núcleos de sedimentos para la reconstrucción climática y ambiental de la región neotropical.

Palabras clave: ostrácodos lacustres, Lago Petén Itzá, Guatemala, Neotrópicos, taxonomía, Physocypria globula.

\section{REFERENCES}

Albrecht, C. \& T. Wilke. 2008. Ancient Lake Ohrid: biodiversity and evolution. Hydrobiologia 615: 103-140.

Alvarez Zarikian, C.A., P.K. Swart, J.A. Gifford \& P.L. Blackwelder. 2005. Holocene paleohydrology of Little Salt Spring, Florida, based on ostracod assemblages and stable isotopes. Palaeogeogr. Palaeoclimateol. Palaeoecol. 225: 134-156.

Anselmetti, F.S., D. Ariztegui, D.A. Hodell, M.B. Hillesheim, M. Brenner, A. Gilli, J.A. McKenzie \& A.D. Mueller. 2006. Late Quaternary climate-induced lake level variations in Lake Petén Itzá, Guatemala, inferred from seismic stratigraphic analysis. Palaeogeogr. Palaeoclimateol. Palaeoecol. 230: 52-69.

Baird, W. 1859. Description of some new recent Entomostraca from Nagpur, collected by the Rev. S. Hislop. Proc. Zool. Soc. Lond. 27: 231-234.

Brady, G.S. \& D. Robertson. 1870. The Ostracoda and Foraminifera of tidal rivers. Ann. Mag. Nat. Hist. 6: 1-33.

Brady, G.S. 1886. Notes on Entomostraca collected by Mr. A. Haly in Ceylon. J. Linn. Soc. Lond. Zool. 19: 293-317.

Brehm, V. 1932. Notizen zur Süßwasserfauna Guatemalas und Mexikos. Zool. Anz. 91: 63-66.

Brehm, V. 1939. La fauna microscópica del Lago Petén, Guatemala. An. Esc. Nac. Cienc. Biol. 1: 173-204.

Brehm, V. 1949. Datos para la fauna de agua dulce de Cuba. Publ. Inst. Biol. Apl. 5: 95-112.

Brenner, M., M. Rosenmeier, D.A. Hodell, J.H. Curtis, F. Anselmetti \& D. Ariztegui. 2002. Limnología y paleolimnología de Petén, Guatemala. Rev. Univ. Valle de Guatemala. 12: 2-9.

Brezonik, P.L. \& J.L. Fox. 1974. The limnology of selected Guatemalan lakes. Hydrobiologia 45: 467-487.

Bridgwater, N.D., T.H.E. Heaton \& S.L. O’Hara. 1999. A late Holocene paleolimnological record from central Mexico, based on faunal and stable-isotope analysis of ostracod shells. J. Paleolimnol. 22: 383-397.

Broodbakker, N. 1984. The distribution and zoogeography of freshwater Ostracoda (Crustacea) in the West Indies, with emphasis on species inhabiting wells. Bijdragen tot de Dierkunde 54: 25-50.

Bronshtein, Z.S. 1947. Fresh-water Ostracoda. Fauna of the USSR, Crustaceans. Vol. 2 (1). Academy of Sciences of the USSR and Zoological Institute. Amerind, New Delhi, Calcutta, India.

Butlin, R.K. \& P. Menozzi. 2000. Open questions in evolutionary ecology: do ostracods have the answers? Hydrobiologia 419: 1-14.

Collado, C., C.H. Fernando \& D. Sephton. 1984. The freshwater zooplankton of Central America and the Caribbean. Hydrobiologia 113: 105-119.

Cross, S.L., P.A. Baker, G.O. Seltzer, S.C. Fritz \& R.B. Dunbar. 2000. A new estimate of the Holocene lowstand level of Lake Titicaca, central Andes, and implications for tropical palaeohydrology. Holocene 10: 21-32.

Curtis, J., D. Hodell \& M. Brenner. 1996. Climate variability on the Yucatan Peninsula (Mexico) during the Past 3500 years, and implications for Maya cultural evolution. Quaternary Res. 46: 37-47.

Curtis, J.H., M. Brenner, D.A. Hodell, R.A. Balser, G.A. Islebe \& H. Hooghiemstra. 1998. A multi-proxy study of Holocene environmental change in the Maya Lowlands of Peten, Guatemala. J. Paleolimnol. 19: 139-159.

Curtis, J., M. Brenner \& D. Hodell. 1999. Climate change in the Lake Valencia Basin, Venezuela, $12600 \mathrm{yr}$ BP to present. Holocene 9: 609-619.

Cusminsky, G.C., P.A. Pérez, A. Schwalb \& R. Whatley. 2005. Recent lacustrine ostracods from Patagonia, Argentina. Rev. Esp. Micropaleontol. 37: 431-450.

Cywinska, A. \& P.D.N. Hebert. 2002. Origins of clonal diversity in the hypervariable asexual ostracode Cypridopsis vidua. J. Evol. Biol. 15: 134-145. 
Daday, E. von. 1898. Mikroskopische süßwasserthiere aus Ceylon. Természetrajzi Füzetek 21: 1-123.

Daday, E. von. 1905. Untersuchungen über die SüßwasserMicrofauna Paraguays. Zoologica: Original-Abhandlungen aus dem Gesamtgebiete der Zoologie 18: $1-374$.

Deevey, E.S., G.B. Deevey \& M. Brenner. 1980. Structure of zooplankton communities in the Peten Lake District, Guatemala, p. 669-678. In W.C. Kerfoot (ed.). The evolution and ecology of zooplankton communities. New England, Hanover, New Hampshire, USA.

Dole-Olivier, M.J., D.M.P. Galassi, P. Marmonier \& M.C.D. Chatelliers. 2000. The biology and ecology of lotic microcrustaceans. Freshwat. Biol. 44: 63-91.

Ferguson, E.G., G.E. Hutchinson \& C.E. Goulden. 1964. Cypria petenensis, a new name for the ostracod Cypria pelagica Brehm 1932. Postilla 80: 1-4.

Furtos, N. 1933. The Ostracoda of Ohio. Bull. Ohio Biol. Surv. 29: 411-524.

Furtos, N. 1934. Two new species of Cypretta (Ostracoda) from the Marquesas Islands and Florida with notes on the distribution of the genus. Pacific Entomol. Surv. Pub. 7: 279-286.

Furtos, N. 1936a. On the Ostracoda from the cenotes of Yucatán and vicinity. Carnegie Institution of Washington, Washington, p. 89-115.

Furtos, N. 1936b. Fresh-water Ostracoda from Florida and North Carolina. Am. Midl. Nat. 17: 491-522.

Griffiths, H.I. \& J.A. Holmes. 2000. Non-marine ostracods and Quaternary palaeoenvironments. QRA Technical Guide No. 8. Quaternary Research Association, London, England.

Goulden, C.E. 1966. The history of Laguna de Petenxil: The animal microfossils. Am. Acad. Arts Sci. Mem. 17: $84-120$

Hillesheim, M., D.A. Hodell, B.W. Leyden, M. Brenner, J.H. Curtis, F.S. Anselmetti, D. Ariztegui, D.G. Buck, T.P. Guilderson, M.F. Rosenmeier \& D.W. Schnurrenberger. 2005. Climate change in lowland Central America during the late deglacial and early Holocene. J. Quaternary Sci. 20: 363-376.

Hodell, D.A., J.H. Curtis \& M. Brenner. 1995. Possible role of climate in the collapse of classic Maya civilization. Nature 375: 391-394.

Hodell, D.A., M. Brenner, J.H. Curtis, R. Medina-González, E. Ildefonso-Chan Can, A. Albornaz-Pat \& T.P.
Guilderson. 2005. Climate change on the Yucatan Peninsula during the Little Ice Age. Quaternary Res. 63: 109-121.

Holmes, J.A. \& A.R. Chivas. 2002. The Ostracoda: applications in quaternary research introduction, p. 1-4. In J.A. Holmes \& A.R. Chivas (eds.). The Ostracoda: Applications in Quaternary Research. Geophysical Monograph Series 131. American Geophysical Union, Washington D.C., USA.

Horne, D.J., A. Cohen \& K. Martens. 2002. Taxonomy, morphology and biology of quaternary and living Ostracoda. p. 5-36. In J.A. Holmes \& A.R. Chivas (eds.). The Ostracoda: Applications in Quaternary Research, Geophysical Monograph 131. American Geophysical Union, Washington D.C., USA.

Keyser, D. 1975. Ostracoden aus den Mangrovegebieten Südwest-Florida (Crustacea: Ostracoda, Podocopa). Abh. Verh. Naturwiss. Ver. Hamburg 18/19: 255 290.

Keyser, D. 1976. Zur Kenntnis der brackigen mangrovebewachsenen Weichböden Südwest-Floridas unter besonderer Berücksitchtigung ihrer Ostracodenfauna. Ph.D. Thesis, Universität Hamburg, Hamburg, Germany.

Klie, W. 1933. Die Ostracoden der Deutschen Limnologischen Sunda-Expedition. Arch. Hydrobiologia 11: 447-502.

Klie, W. 1939. Süßwasserostracoden aus Nordbrasilien. III. Die Gattungen Stenocypris und Dolerocypris. Zool. Anz. 128: 316-320.

Kotzian, C.B. 1974. New fresh-water Ostracodes of the genus Chlamydotheca from Brazil. Ecology, geographic distribution and stratigraphical position. An. Acad. Brasil Cienc. 46: 423-467.

Laprida, C. 2006. Ostrácodos recientes de la llanura pampeana, Buenos Aires, Argentina: ecología e implicaciones paleolimnológicas. Ameghiniana 43: 181-204.

Leyden, B., M. Brenner, T. Whitmore, J. Curtis, D. Piperno \& B. Dahlin. 1996. A record of long-and short term climatic variation from northwest Yucatán: Cenote San José Chulchacá, p. 30-50. In S.L. Fedick (ed.). The Managed Mosaic: Ancient Maya Agriculture and Resource Use. University of Utah, Salt Lake City, USA.

Löffler, H. 1961. Zur Systematik und Ökologie der chilenischen Süßwasserentomostraken. Beitr. Neotrop. Fauna 2: 143-222. 
MARN-AMPI. 2008. Línea de Base Territorial para la Cuenca. Proyecto GU-T1021. Informe final. Ministerio de Medio Ambiente, Guatemala, Guatemala.

Markgraf, V., J.P. Bradbury, A. Schwalb, S.J. Burns, C. Stern, D. Ariztegui, A. Gilli, F.S. Anselmetti, S. Siten \& N. Maidana. 2003. Holocene paleoclimates of southern Patagonia: limnological history of Lago Cardiel, Argentina. Holocene 13: 581-591.

Martens, K. 1984. Annotated Checklist of Non-Marine Ostracods (Crustacea, Ostracoda) from African Inland Waters, Institute of Zoology, Belgium. Musée royal del'Afrique Centrale Tervuren, Documentation zoologique 20: 1-51.

Martens, K. 1989. On the systematic position of the Eucypris clavata-group, with a description of Trajancypris gen. nov. (Crustacea, Ostracoda). Arch. Hydrobiol. 83: 227-251.

Martens, K. \& F. Behen. 1994. A checklist of the recent non-marine ostracods (Crustacea, Ostracoda) from the inland waters of South America and adjacent islands. Travaux scientifiques du musee national d'histoire naturelle de Luxembourg 22: 1-84.

Martens, K. 2001. Taxonomy of the Herpetocypridinae (Ostracoda, Cyprididae). Crustaceana 74 : 295-308.

Martens, K., I. Schön, C. Meisch \& D.J. Horne. 2008. Global diversity of ostracods (Ostracoda, Crustacea) in freshwater. Hydrobiologia 595: 185-193.

Meisch, C. 2000. Freshwater Ostracoda of Western and Central Europe. Süßwasserfauna von Mitteleuropa. Spektrum Akademischer Verlag GmbH, Heidelberg, Berlin, Germany.

Meisch, C., N. Mary-Sasal, J.P. Colin \& K. Wouters. 2007. Freshwater Ostracoda (Crustacea) collected from the islands of Futuna and Wallis, Pacific Ocean, with a check-list of the non-marine Ostracoda of the Pacific Islands. Bull. Soc. Nat. Luxemb. 108: 89-103.

Mezquita, F., J.R. Roca, J.M. Reed \& G. Wansard. 2005. Quantifying species-environment relationships in non-marine Ostracoda for ecological and paleoecological studies: Examples using Iberian data. Palaeogeogr. Palaeoclimateol. Palaeoecol. 225: 93-117.

Müller, A., G.A. Islebe, M.B. Hillesheim, D.A. Grzesik, F.S. Anselmetti, D. Ariztegui, M. Brenner, J.H. Curtis, D.A. Hodell \& K.A. Venz. 2009. Climate drying and associated forest decline in the lowlands of northern Guatemala during the late Holocene. Quaternary Res. 71: 133-141.
Okubo, I. 1973. Cypretta seurati Gauthier, 1929, from Japan (Ostracoda, Cyprididae). Proc. Jap. Soc. Sist. Zool. 9: 1-6.

Pérez, L., G. Alfaro, M. Palmieri, M. Dix, M. Maldonado, G. Islebe, B. Scharf \& A. Schwalb. 2008. Paleoclima y paleoecología de las tierras bajas del norte de los neotrópicos: investigación limnológica y extracción de sedimentos del lago Petén Itzá (Guatemala). Rev. Univ. Valle de Guatemala 18: 65-83.

Pérez, L., B. Scharf \& A. Schwalb. 2009. Living and fossil ostracode species assemblages from the Yucatán Peninsula as indicators of environmental change, a contribution to the Lago Petén Itzá Drilling Project. IODP/ICDP Kolloquium 16-18.03, Postdam, Germany: 119-121.

Pérez, L., J. Lorenschat, R. Bugja, M. Brenner, B. Scharf \& A. Schwalb. 2010. Distribution, diversity and ecology of modern freshwater ostracodes (Crustacea), and hydrochemical characteristics of Lago Petén Itzá, Guatemala. J. Limnol. 69: 146-159.

Purper, I. 1974. Cytheridella boldii Purper sp. nov. (Ostracoda) from Venezuela and a revision of the genus Cytheridella Daday, 1905. An. Acad. Bras. Cienc. 46: 635-662.

Roessler, E.W. 1990a. Estudios sobre los ostrácodos de agua dulce en Colombia. VI-IV. Estudio taxonómico del grupo "Strandesia psittacea psittacea (Sars, 1901)". Caldasia 16: 215-230.

Roessler, E.W. 1990b. Estudios taxonómicos, ontogenéticos, ecológicos y etológicos sobre los ostrácodos de agua dulce en Colombia (Ostracoda, Podocopida, Cyprididae). VI. Estudio taxonómico del género Strandesia Stuhlmann 1888-Parte III. El grupo "Strandesia elliptica (Sars 1901)". Rev. Acad. Colomb. Cienc. Exactas Fis. Nat. 16: 795-804.

Rosenmeier, M., D. Hodell, M. Brenner, J. Curtis, J. Martin, F. Anselmetti, D. Ariztegui \& T. Guilderson. 2002a. Influence of vegetation change on watershed hydrology: implications for paleoclimatic interpretation of lacustrine $\delta^{18} \mathrm{O}$ records. J. Paleolimnol. 27: 117-131.

Rosenmeier, M., D. Hodell, M. Brenner \& J. Curtis. 2002b. A 4000-year lacustrine record of environmental change in the southern Maya Lowlands, Petén, Guatemala. Quaternary Res. 57: 183-190.

Rossetti, G. \& K. Martens. 1996. Redescription and morphological variability of Darwinula stevensoni (Brady and Robertson, 1870) (Crustacea, Ostracoda). Bull. Inst. R. Sci. Nat. Belgique Biol. 66: 73-92. 
Sars, G. 1889. On some freshwater Ostracoda and Copepoda, raised from dried Australian mud. Christ. Vidensk. Selsk. Forhandl. 8: 1-79.

Schwalb, A. 2003. Lacustrine ostracodes as stable isotope recorders of late-glacial and holocene environmental dynamics and climate. J. Paleolimnol. 29: 256-351.

Smith, A.J. \& D.J. Horne. 2002. Ecology of marine, marginal marine and nonmarine Ostracodes, p. 37-64. In J.A. Holmes \& A.R. Chivas (eds.). The Ostracoda: Applications in Quaternary Research, Geophysical Monograph 131. American Geophysical Union, Washington D.C., USA.

Smith, R. \& T. Kamiya. 2006. Six new species of fresh and brackish water ostracods (Crustacea) from Yakushima, Southern Japan. Hydrobiologia 559: 331-355.

Smith, R. \& T. Kamiya. 2008. The ontogeny of two species of Darwinuloidea (Ostracoda, Crustacea). Zool. Anz. 247: 275-302.

Swain, F.M. \& J.M. Gilby. 1964. Ecology and taxonomy of Ostracoda and an alga from Lake Nicaragua. Publ. Staz. Zool. Napoli 33: 361-386.

Sohn, G. \& L. Kornicker. 1972. Morphology of Cypretta kawatai Sohn and Kornicker, 1972 (Crustacea,
Ostracoda), with a discussion of the genus. Smithsonian Contrib. Zool. 141: 1-28.

Tressler, W.L. 1947. A check list of the known species of North American freshwater Ostracoda. Am. Midl. Nat. 38: 698-707.

Viehberg, F. 2004. Paleolimnological study based on ostracods (Crustacea) in late-glacial and Holocene deposits of lake Krakawer See (Mecklenburg-Vorpommern NE Germany). Studia Quaternaria 21: 109-115.

Whitmore, T.J., M. Brenner, J.H. Curtis, B.H. Dahlin \& B.W. Leyden. 1996. Holocene climatic and human influences on lakes of the Yucatán Península, Mexico: an interdisciplinary paleolimnological approach. Holocene 6: 273-287.

Willard, D.A., C.E. Bernhardt, G.R. Brooks, T.M. Cronin, T. Edgar \& R. Larson. 2007. Deglacial climate variability in central Florida, USA. Palaeogeogr. Palaeoclimateol. Palaeoecol. 251: 366-382.

Würdig, N.L. 1983. Fresh and brackish-water Ostracodes from the east coast of the State of Rio Grande Do Sul, Brazil. Applications of Ostracoda. Proc. $8^{\text {th }}$ Int. Symp. Ostracoda. Houston, Texas, USA. 